\title{
Effects of cadmium and zinc on Procambarus clarkii: Simulation of the Aznalcóllar mining spill
}

\section{Efectos de cadmio y zinc en Procambarus clarkii: Simulación del accidente minero de Aznalcóllar}

\author{
M.L. Martín-Díaz ${ }^{1 *}$ \\ S.R. Tuberty ${ }^{2}$ \\ C.L. McKenney Jr. ${ }^{3}$ \\ D. Sales ${ }^{1}$ \\ T.A. Del Valls ${ }^{1}$ \\ ${ }^{1}$ Facultad de Ciencias del Mar y Ambientales \\ Campus Río San Pedro s/n \\ 11510 Puerto Real, Cádiz, Spain \\ *E-mail: laura.martin@uca.es \\ 2 University of West Florida \\ Center for Environmental Diagnostics and Bioremediation \\ One Sabine Island Dr. \\ Gulf Breeze, FL 32561, USA \\ ${ }^{3}$ US Environmental Protection Agency NHEERL \\ Gulf Ecology Division \\ One Sabine Island Dr. \\ Gulf Breeze, FL 32561, USA
}

Recibido en junio de 2003; aceptado en mayo de 2004

\begin{abstract}
Female red swamp crayfish, Procambarus clarkii, were exposed for 21 days in the laboratory to different dissolved concentrations of zinc $\left(1000 \mu \mathrm{g} \mathrm{L} \mathrm{L}^{-1}\right.$ and $\left.3000 \mu \mathrm{g} \mathrm{L}{ }^{-1}\right)$ and cadmium $\left(10 \mu \mathrm{g} \mathrm{L} \mathrm{L}^{-1}\right.$ and $\left.30 \mu \mathrm{g} \mathrm{L}{ }^{-1}\right)$, determined in the Guadiamar River after the Aznalcóllar mining spill (SW Spain). Female gonadosomatic and hepatosomatic indexes were analyzed at the end of the bioassay, and a general decrease in the gonadosomatic index and increase in the hepatosomatic index were observed in individuals at the same maturation stage, exposed to increasing heavy metal concentrations. Only the decrease in the gonadosomatic index values was significant at the highest zinc concentration. Decreases in gonadosomatic indexes were associated with reduced fecundity.
\end{abstract}

Key words: Aznalcóllar mining spill, heavy metals, crustaceans, gonadosomatic index, hepatosomatic index.

\section{Resumen}

Hembras de cangrejo rojo, Procambarus clarkii, se expusieron en el laboratorio durante 21 días a diferentes concentraciones de zinc $\left(1000 \mu \mathrm{g} \mathrm{L}-1\right.$ y $\left.3000 \mu \mathrm{g} \mathrm{L}^{-1}\right)$ y de cadmio $\left(10 \mu \mathrm{g} \mathrm{L}-1\right.$ y $\left.30 \mu \mathrm{g} \mathrm{L}{ }^{-1}\right)$, determinadas en el Río Guadiamar tras el accidente minero de Aznalcóllar (SO de España). Se analizaron los índices gonadosomáticos y hepatosomáticos de las hembras al final del bioensayo, observándose una disminución del índice gonadosomático y un aumento del hepatosomático en los individuos que se encontraban en el mismo estado de maduración, expuestos a un incremento de concentraciones de metales. Únicamente se observó una disminución significativa del índice gonadosomático a la mayor concentración de zinc. La disminución en los índices gonadosomáticos se ha relacionado con una disminución de la fecundidad.

Palabras clave: accidente minero de Aznacóllar, metales pesados, crustáceos, índice gonadosomático, índice hepatosomático.

\section{Introduction}

The Guadalquivir River is the main river of the southern Iberian Peninsula and shelters different kinds of ecologically important species. The Aznalcóllar mining spill poured into the

\section{Introducción}

El Río Guadalquivir es el río más importante del sur de la Península Ibérica, y alberga diferentes tipos de especies ecológicamente muy importantes. Duarnte el accidente minero 
nearby Guadiamar River, which flows into the Guadalquivir estuary, almost $6 \mathrm{Hm}^{3}$ of mud and acidic waters, with high concentrations of metals in solution, including $\mathrm{Cd}, \mathrm{Cu}, \mathrm{Mn}, \mathrm{As}, \mathrm{Pb}$ and especially $\mathrm{Zn}$. Consequently, the sediment and water quality of the river and estuary was negatively affected (GutiérrezYurrita and Montes, 1998; Riba et al., 2002).

Environmental contamination represents a threat to aquatic species world-wide (Guillette et al., 1998). The red swamp crayfish, Procambarus clarkii (Girard, 1852), a native of the southern United States and introduced into the southern Iberian Peninsula, has been intensely studied as a bioindicator of the effects of pollutants and because of its economic importance. Extensive literature is available on heavy metals and this crayfish: effects in ovarian development on this species have been studied by Naqvi and Howell (1993) and Reddy et al. (1997). Ovarian development, a hormonally-regulated process, can serve as an indicator of the condition of the gonads (Fingerman et al., 1998). It can be determined through the variation of the gonadosomatic index that represents the percentage of the weight of the animal due to the gonad, and has been studied in vivo in the effect of $\mathrm{Cd}$ on the gonadosomatic index of P. clarkii (Reddy et al., 1997). The relationship between ovarian maturation and development of the hepatopancreas, and its dependence on hormonally-regulated processes, made the hepatopancreas an object of study at the same time as the ovary. The hepatosomatic index, the percentage of the weight of the animal due to the hepatopancreas, is also important because of its role in ovarian maturation, and it could be an indicator of the condition of this organ.

The hepatopancreas synthesizes and releases serum vitellogenin, which is immunologically identical to lipovitellin, the major high-density lipoprotein in the fully-developed ovary (Paulus and Laufer, 1987). Reproductive processes in the brachyurans, including vitellogenesis, are governed by neuralhormonal mechanisms (Adiyodi and Adiyodi, 1970). Therefore, in addition to the oocytes, the cells in the hepatopancreas that synthesize vitellogenin are potential targets for hormonal factors regulating reproduction (Paulus and Laufer, 1987).

This study was designed as a preliminary evaluation of the effect of different concentrations of $\mathrm{Cd}$ and $\mathrm{Zn}$, using real dissolved concentrations from a mining spill episode, on the development of the ovaries and its relationship with changes in the contribution of the hepatopancreas to the total weight of $P$. clarkii. At the same time, the gonadosomatic and hepatosomatic indexes were tested as biomarkers of environmental heavy metal contamination.

\section{Material and methods}

\section{Approach}

The present study was performed taking into account heavy metal concentrations of dissolved $\mathrm{Cd}$ and $\mathrm{Zn}$, previously determined the first months after the spill during the monitoring of de Aznalcóllar se vertieron en el Río Guadiamar que desemboca en el estuario del río Guadalquivir, cerca de $6 \mathrm{Hm}^{3}$ de lodo y aguas ácidas, con altas concentraciones de metales en solución, incluidos $\mathrm{Cd}, \mathrm{Cu}, \mathrm{Mn}, \mathrm{As}, \mathrm{Pb}$ y especialmente $\mathrm{Zn}$. Como consecuencia, la calidad del sedimento y del agua del río y del estuario se vio afectada significativamente (GutiérrezYurrita y Montes, 1998, Riba et al., 2002).

La contaminación medioambiental supone una amenaza para las especies acuáticas a nivel mundial (Guillette et al., 1998). El cangrejo rojo, Procambarus clarkii (Girard, 1852), una especie autóctona del sur de Estados Unidos, introducida en el sur de la Península Ibérica, ha sido intensamente estudiada como bioindicador de los efectos de contaminantes y por su importancia económica. Existe una amplia bibliografía con relación a los efectos de los metales pesados en este cangrejo. Particularmente Naqvi y Howell (1993) y Reddy et al. (1997) estudiaron sus efectos en el desarrollo ovárico de esta especie . El desarrollo ovárico, un proceso regulado por hormonas, puede servir como indicador del estado de las gónadas (Fingerman et al., 1998). Puede ser determinado a través de la variación del índice gonadosomático (GSI, por sus siglas en inglés), que representa el porcentaje del peso del animal debido a la gónada, y el efecto del cadmio sobre el Índice Gonadosomático de P. clarkii ha sido estudiado in vivo (Reddy et al., 1997). La relación entre el desarrollo ovárico y el desarrollo del hepatopáncreas, y su dependencia con los procesos regulados por hormonas, hacen del hepatopáncreas objeto de estudio al mismo tiempo que el ovario. El índice hepatosomático (HSI, por sus siglas en inglés), o porcentaje del peso del individuo debido al hepatopáncreas, es también importante por la función que desempeña en la maduración del ovario, y puede ser un idicador del estado de este órgano. El hepatopancreas sintetiza y vierte vitelogenina, que es inmunologicamente idéntica a la lipovitelina, la lipoproteína de mayor densidad en el ovario totalmente maduro (Paulus y Laufer, 1987). Los procesos reproductivos en brachyuros, incluyendo la vitelogénesis, están gobernados por mecanismos neurohormonales (Adiyodi y Adiyodi, 1970). Por lo tanto, además de los ovocitos, las células en el hepatopáncreas que sintetizan vitelogenina constituyen blancos potenciales para los factores hormonales que regulan la reproducción (Paulus y Laufer, 1987).

Este estudio se diseñó como una evaluación preliminar del efecto de diferentes concentraciones de $\mathrm{Cd}$ y $\mathrm{Zn}$ utilizando concentraciones disueltas reales de un episodio de contaminación minera, sobre el desarrollo de los ovarios y su relación con cambios en la contribución del hepatopáncreas al peso total de P. clarkii. Paralelamente se analizaron el IGS y el IHS como biomarcadores de contaminación por metales pesados en el medio ambiente.

\section{Material y métodos}

\section{Enfoque}

El presente estudio se realizó teniendo en cuenta las concentraciones disueltas de los metales pesados $\mathrm{Cd}$ y Zn, 
the impact on the Guadiamar River and surrounding areas by Junta de Andalucía (www.cma.junta-andalucia.es). Intermoult female $P$. clarkii were obtained from the Department of Wildlife and Fisheries, Mississippi State University, USA. The animals were placed in a laminar-flow holding tank with filtered $(6 \mathrm{~mm})$ and dechlorinated fresh water and allowed to acclimate for two weeks prior to exposures. The tank conditions were maintained at $25^{\circ} \mathrm{C}$ and a $12: 12 \mathrm{~h}$ light:dark cycle. The material used for the present experiment was previously washed with nitric acid (10\%) and cleaned with distilled water (Milli-Q) to avoid metal contamination. Crayfish were exposed for 21 days to $1000 \mu \mathrm{g} \mathrm{L}^{-1}$ and $3000 \mu \mathrm{g} \mathrm{L} \mathrm{L}^{-1}$ of $\mathrm{Zn}$ (zinc chloride), and $10 \mu \mathrm{g} \mathrm{L}^{-1}$ and $30 \mu \mathrm{g} \mathrm{L}^{-1}$ of Cd (cadmium chloride) (Sigma) in filtered and dechlorinated fresh water. A single set of reference females was used. Eight female P. clarkii were randomly placed in 30-L tanks with 5-L volume of exposure solutions (filtered dechlorinated fresh water and metal stock solution). Chelipeds were removed in order to reduce antagonistic behavior and cannibalism. The exposure solutions were replaced every three days and the animals were fed on a diet of frozen brine shrimp just prior to the water change to reduce fouling of the exposure solutions. Exposure conditions were as described for the acclimation period.

\section{Determination of the gonadosomatic and hepatosomatic indexes}

At the end of the experiment, the crayfish were weighed and dissected, and their ovaries and hepatopancreas were removed and weighed. The gonadosomatic index or GSI (ratio of wet weight of ovaries to whole body wet weight $\times 100$ ) and the hepatosomatic index or HSI (ratio of weight of the midgut gland to whole body weight $\times 100$ ) were calculated. Ovarian maturation in crustaceans includes a color change and an enlargement in size of the ovaries as the oocytes proliferate and increase in diameter during yolk incorporation (CharniauxCotton and Payen, 1998). In order to determine the ovarian maturation stage, a sample of ovarian tissue was examined under a light microscope to estimate the oocyte diameter by ocular measurements. Although eight female crayfish were chosen for each treatment in the present bioassay, only females in the same maturation stage (stage VI) were selected for analysis of the results.

The GSI and HSI data obtained for individuals exposed to $\mathrm{Cd}$ and $\mathrm{Zn}$ were compared to those belonging to the control treatment by Student's $t$-test with significance set at the $95 \%$ and $99 \%$ confidence intervals.

\section{Results}

\section{Effect of Cd and Zn on the gonadosomatic index}

The ovarian stage of all the females used for the data analysis (control and metal treatments) was the same, stage VI, and the diameter of the oocytes was $10 \mu \mathrm{m}$. This makes it possible previamente determinadas durante el control del impacto del accidente minero por la Junta de Andalucía (www.cma.juntaandalucia.es) en el Río Guadiamar y las áreas adyacentes, durante los primeros meses después del accidente. Se obtuvieron hembras de Procambarus clarkii en estado de intermuda del Wildlife and Fisheries Department, Mississippi State University, EUA. Los animales se colocaron, para su aclimatación durante dos semanas y antes de comenzar el bioensayo, en un tanque con flujo laminar de agua dulce filtrada (6 mm) y desclorinada. Las condiciones del tanque se mantuvieron a $25^{\circ} \mathrm{C}$ de temperatura y a un ciclo de luz:oscuridad 12:12 horas. El material utilizado para el presente experimento fue lavado previamente con ácido nítrico al $10 \%$ y con agua destilada (Milli-Q) para evitar la contaminación por metales pesados. Los cangrejos se expusieron a $1000 \mu \mathrm{g} \mathrm{L}^{-1}$ y $3000 \mu \mathrm{g} \mathrm{L}{ }^{-1}$ de Zn (cloruro de zinc), y $10 \mu \mathrm{g} \mathrm{L}^{-1}$ y $30 \mu \mathrm{g} \mathrm{L}^{-1}$ de Cd (cloruro de cadmio) (SIGMA) en agua dulce filtrada y desclorinada. El bioensayo se realizó por duplicado. Se colocaron aleatoriamente 8 hembras de $P$. clarkii en tanques de $30 \mathrm{~L}$ de capacidad con un volumen de $5 \mathrm{~L}$ de soluciones de exposición (agua dulce filtrada y desclorinada junto con una solución stock de metal). Para reducir el comportamiento antagónico y el canibalismo, se cortaron las pinzas a los individuos. Las soluciones de exposición se cambiaron cada 3 días, tras alimentar a los individuos con gamba en salmuera congelada con el fin de reducir la suciedad en las soluciones de exposición. Las condiciones de exposición fueron las mismas que las descritas para el período de aclimatación.

\section{Determinación del índice gonadosomático y hepatosomático}

Al final del experimento, se pesaron los cangrejos, se diseccionaron, se sustrajeron sus ovarios y hepatopáncreas, y fueron pesados. Se calcularon el GSI (razón del peso de los ovarios y el peso del individuo $\times 100$ ) y el HSI (razón del peso del hepatopáncreas y el peso del individuo ×100). En crustáceos, la maduración del ovario incluye un cambio de color y un aumento el tamaño de los ovarios mientras proliferan los ovocitos y aumenta el diámetro durante la incorporación a la yema. (Charniaux-Cotton y Payen, 1998). Para determinar el estado de maduración del ovario, se tomó una muestra de tejido del mismo, se examinó en un microscopio electrónico y se estimó el diámetro del ovocito mediante la medición del ocular. Aunque para el presente bioensayo se usaron ocho hembras por tratamiento, únicamente se seleccionaron para el análisis de los resultados hembras en el mismo estado de maduración (Estado VI).

Los datos de GSI y HSI obtenidos de los individuos expuestos a Cd y Zn se compararon con los pertenecientes al tratamiento control a través de un test de $t$ de Student con una significancia del 95\% y el 99\%. 
to compare GSI means of all female crayfish treated in this experiment at the same ovarian maturation stage. The GSI means belonging to the different heavy metal exposures and control are given in table 1 . Increasing $\mathrm{Zn}$ concentration exposure resulted in a decrease in the GSI values. The values obtained were lower than those determined for control crayfish, although only the GSI mean of the individuals exposed to the highest $\mathrm{Zn}$ concentration (3000 $\mu \mathrm{g} \mathrm{L}^{-1}$ ) was significantly different to the control $(P<0.01)$. This response showed that exposure to the highest $\mathrm{Zn}$ concentration significantly affects the development of the oocytes.

The GSI means of the crayfish exposed to Cd did not show a clear relationship with the Cd concentration values, like that observed in crayfish exposed to Zn. The GSI values for animals exposed to $\mathrm{Cd}$ were lower, but not significantly different to the control.

\section{Effect of Cd and Zn on the hepatosomatic index}

The HSI was determined for the same animals used in the GSI determination. The HSI means of the individuals exposed to the different heavy metal concentrations and control are given in table 2. Results show higher HSI means in animals exposed to $\mathrm{Zn}$ and $\mathrm{Cd}$ than those means obtained in the negative toxicity control, although they were not significantly different. Increasing $\mathrm{Zn}$ concentration was related to an increase in HSI values; nevertheless, crayfish exposed to $\mathrm{Cd}$ did not show a clear relationship with Cd concentration values.

\section{Discussion}

Studies of the effects of contaminants on gonad development of crustaceans have been relatively few in number (Fingerman et al., 1998). These parameters, in particular GSI, can serve as indicators of the condition of the gonads (Fingerman et al., 1998). They not only provide the information that an effect biomarker can give, but also provide information about the effect in future generations because of the role of gonad maturation in reproduction. The GSI has been

Table 1. Mean and standard deviation of the gonadosomatic index (GSI). The asterisk indicates significant differences with the control treatment $(P<0.01)$.

Tabla 1. Media y desviación estándar del índice gonadosomático (GSI). El asterisco representa diferencias significativas con el control $(P<0.01)$.

\begin{tabular}{rccl}
\hline Group & Treatment & $\begin{array}{c}\text { Crayfish } \\
\text { used }\end{array}$ & $\begin{array}{c}\text { GSI } \\
\text { (mean } \pm \text { SEM) }\end{array}$ \\
\hline I & Control & 4 & $3.97 \pm 0.97$ \\
II & $1000 \mu \mathrm{g} \mathrm{L}^{-1} \mathrm{Zn}$ & 4 & $3.18 \pm 0.29$ \\
III & $3000 \mu \mathrm{g} \mathrm{L}^{-1} \mathrm{Zn}$ & 4 & $1.66 \pm 0.20^{*}$ \\
IV & $10 \mu \mathrm{g} \mathrm{L}^{-1} \mathrm{Cd}$ & 5 & $2.38 \pm 0.15$ \\
$\mathrm{~V}$ & $30 \mu \mathrm{g} \mathrm{L}^{-1} \mathrm{Cd}$ & 5 & $3.39 \pm 0.92$ \\
\hline
\end{tabular}

\section{Resutados}

\section{Efectos del Cd y Zn en el índice gonadosomático}

El índice ovárico para todas las hembras utilizadas en el análisis de los datos (tratamiento control y metal) fue el mismo, estado seis, y, el diámetro de los ovocitos, 10 micrómetros. Este aspecto permite la posibilidad de comparar las medias de los GSI de todas las hembras tratadas en este experimento en el mismo estado de maduración del ovario. En la tabla 1 se presentan las medias de los GSI pertenecientes a diferentes exposiciones a metales pesados y el control. El aumento de la concentración de exposición a Zn conlleva una disminución de los valores de GSI. Los valores obtenidos eran más pequeños que los determinados en los cangrejos control, aunque sólo la media del GSI de aquellos individuos expuestos a la concentración más alta de Zn (3000 $\left.\mu \mathrm{g} \mathrm{L}^{-1}\right)$ fue significativamente diferente a la del control $(P<0.01)$. Esta respuesta muestra cómo la exposición a la concentración más alta de Zn afecta significativamente al desarrollo de los ovocitos.

Las medias de los GSI de los cangrejos expuestos a Cd no mostraron una relación clara con la concentración del mismo, como la observada en los cangrejos expuestos a Zn. Los valores del GSI para los animales expuestos a Cd fueron más pequeños que el control pero no significativamente diferentes.

\section{Efectos de Cd y Zn en el índice hepatosomático}

El Índice Hepatosomático se determinó en los mismos individuos utilizados para la determinación del GSI. En la tabla 2 se muestran las medias de los HSI de los individuos expuestos a diferentes concentraciones de metales pesados y control. Los resultados mostraron medias más altas de HSI en animales expuestos a Zn y Cd que aquellas obtenidas en el control negativo de toxicidad, aunque no fueron significativamente diferentes. El aumento en la concentración de Zn conllevó un aumento en los valores de HSI, sin embargo, los cangrejos expuestos a Cd no mostraron una relación clara con los valores de concentración de Cd.

Table 2. Mean and standard deviation of the hepatosomatic index (HSI) for different treatments.

Tabla 2. Media y desviación estándar del índice hepatosomático (HSI).

\begin{tabular}{rccc}
\hline Group & Treatment & $\begin{array}{c}\text { Crayfish } \\
\text { used }\end{array}$ & $\begin{array}{c}\text { HSI } \\
\text { (mean } \pm \text { SEM) }\end{array}$ \\
\hline I & Control & 4 & $4.78 \pm 0.36$ \\
II & $1000 \mu g$ L$^{-1} \mathrm{Zn}$ & 4 & $5.04 \pm 0.76$ \\
III & $3000 \mu \mathrm{g} \mathrm{L}^{-1} \mathrm{Zn}$ & 4 & $5.62 \pm 0.65$ \\
IV & $10 \mu \mathrm{g} \mathrm{L}^{-1} \mathrm{Cd}$ & 5 & $5.60 \pm 0.70$ \\
$\mathrm{~V}$ & $30 \mu \mathrm{g} \mathrm{L}^{-1} \mathrm{Cd}$ & 5 & $5.09 \pm 0.37$ \\
\hline
\end{tabular}


used in studies developed to determine the effect of the injection of methyl farnesoate (Laufer et al., 1998), the effect of temperature and photoperiod (Daniels et al., 1994), and the effect of the injection of Cd (Reddy et al., 1997) on P. clarkii. The stimulation or inhibition of this index has been directly related to stimulation or inhibition of ovarian maturation. Only in the study developed by Laufer et al. (1998) were both criteria (size of the ovary relative to individual body weight (GSI) and color to assess maturation) taken into account together to assess the effect of the injection of methyl farnesoate on ovarian maturation in females of red swamp crayfish $P$. clarkii, resulting in differences of GSI values and oocytes with similar diameters.

The reduction in GSI values observed in the present study, for crayfish exposed to $\mathrm{Cd}$ and $\mathrm{Zn}$ (only significant at the highest concentration) compared with the control, could be due to an increase or decrease in total body weights; however, no differences in body weight were found between animals exposed to $\mathrm{Cd}$ or $\mathrm{Zn}$ and the control. The decrease in GSI values obtained for crayfish exposed to both metals and concentrations, in individuals at the same stage of development and similar oocyte diameter, may be due to a fewer number of oocytes maturing in response to the heavy metal treatment, resulting in reduced fecundity. Although the number of developing oocytes was not counted in this study, this speculation is not wholly improbable, because $\mathrm{Cd}$ was found to reduce fecundity and hatching success of P. clarkii at $0.5 \mathrm{mg}$ of Cd per gram body weight (Naqvi and Howell, 1993), and all broods of the cladoceran Moina irrasa had a reduced number of progeny at concentrations of $200 \mu \mathrm{g} \mathrm{L}^{-1}$ of Zn (Zou, 1997).

Increases in HSI values were related to decreases in GSI values in every treatment. Deposition of energy reserves in the hepatopancreas (increase of hepatopancreas weight) may have been required before yolk deposition in the eggs (increased ovary weight).

Only individuals at the same stage of ovarian development and with similar oocyte diameter were used in this study. This fact and the mortality registered in all treatments and control (25\%) due to cannibalism between individuals, did not allow greater analysis of the results because of the small number of replicates. Nevertheless, the data obtained can be taken into account as a first approach.

The concentrations of heavy metals released during the first days of the Aznalcóllar mining spill produced adverse biological effects (Riba et al., 2003). The effects produced on the reproductive efficiency of native species could not be measured at that time, but the concentrations of heavy metals measured could have affected the organisms during the first months of the accidental spill. In the present study, hormonally-regulated processes were used as indicators of the health of the environment, and tested in the laboratory with real environmental concentrations. Nevertheless, more studies regarding the use of GSI and HSI values as indicators of toxicity in the environment are necessary, because although a direct relationship was shown between these indexes and dissolved

\section{Discusión}

Existe un número muy reducido de estudios de los efectos de los contaminantes en el desarrollo gonadal de crustáceos (Fingerman et al.,1998). Estos parámetros, especialmente el GSI, pueden servir como indicadores de la condición de las gónadas (Fingerman et al., 1998). No sólo proporciona la información que un biomarcador de efecto puede proporcionar, sino que también proporciona información sobre el efecto en futuras generaciones por la función de la maduración de la gónada en la reproducción. El GSI se ha utilizado en estudios para la determinación del efecto de la inyección de metilfarnesoato (MF) (Laufer et al., 1998), el efecto de la temperatura y el fotoperíodo (Daniels et al., 1994) o el impacto de la inyección de Cd (Reddy et al., 1997) todo sobre P. clarkii. La estimulación o inhibición de este índice se ha relacionado directamente con la estimulación o inhibición de la maduración del ovario. Sólo en los estudios desarrollados por Laufer et al. (1998) ambos criterios, tamaño del ovario con respecto al peso del cuerpo de individuo (índice gonadosomático, GSI) y color para evaluar la maduración, se tomaron en cuenta conjuntamente para evaluar el efecto de la inyección de MF en la maduración del ovario en hembras de cangrejo rojo P. clarkii. Como resultado se obtuvieron diferencias en el GSI y ovocitos con diámetros similares.

La reducción en el GSI observada en el presente estudio para los cangrejos expuestos a Cd y Zn (sólo significativa para la concentración más alta de Zn), comparada con el control, puede deberse a un aumento o reducción del peso de los individuos. Sin embargo, no se observaron diferencias en el peso de los individuos expuestos a $\mathrm{Cd}$ y $\mathrm{Zn}$ con el control. La disminución en los valores del GSI observada en los individuos en el mismo estado de maduración e igual diámetro de ovocitos, expuestos a ambos metales y concentraciones, puede ser debida a la presencia de un menor número de ovocitos como respuesta al tratamiento con metales pesados y, como consecuencia, una reducción en la fecundidad. Aunque en este estudio no se contó el número de ovocitos, este razonamiento no es del todo improbable porque se ha observado que el Cd redujo la fecundidad y el éxito de eclosión de P. clarkii expuesto a $0.5 \mathrm{mg}$ de $\mathrm{Cd}$ por gramo de peso del individuo (Naqvi y Howell, 1993) así como el Zn en el cladócero Moina irrasa, donde el número de progenitores se redujo a concentraciones de $200 \mu \mathrm{g} \mathrm{L}^{-1}$ de Zn (Zou, 1997).

Para cada tratamiento, aumentos en los valores de HSI se relacionaron con disminuciones en los valores de GSI. La acumulación de las reservas de energía en el hepatopáncreas (aumento del peso del hepatopáncreas) puede haberse requerido antes de la acumulación en la yema de los huevos (aumento en el peso del ovario).

En el presente estudio sólo se han utilizado individuos en el mismo estado de desarrollo ovárico y con diámetro de ovocitos similar. Esto, y la mortalidad registrada en todos los tratamientos y el control (25\%) debido al canibalismo entre los individuos, no permitieron el desarrollo de un estudio más 
Zn concentrations, they did not show a clear trend in animals exposed to $\mathrm{Cd}$.

\section{Acknowledgements}

This research was supported by a grant from the PICOVER program (Consejería de Medio Ambiente, Junta de Andalucía, Spain) and performed at the US Environmental Protection Agency, Pensacola, Florida. The authors would like to thank the members of the EPA for their help and support, and especially Kathy, Tere and Andy for their tireless efforts and friendship during the course of this study.

\section{References}

Adiyodi, K.G. and Adiyodi, R.G. (1970). Endocrine control of reproduction in decapod Crustacea. Biol. Rev., 45: 121-165.

Charniaux-Cotton, H. and Payen, G. (1988). Crustacean reproduction. In: H. Laufer and G.H. Downer (eds.), Endocrinology of Selected Invertebrate Types. Alan R.Liss, New York, pp. 279-303.

Daniels, W.H., D’Abramo, L.R. and Graves, K.F. (1994). Ovarian development of female red swamp crayfish (Procambarus clarkii) as influenced by temperature and photoperiod. J. Crus. Biol., 14(3): 530-537.

Fingerman, M., Jackson, N.C. and Nagabhushanam, R. (1998). Hormonally-regulated functions in crustaceans as biomarkers of environmental pollution. Comp. Biochem. Physiol., Part C, 120: 343-350.

Guillette, L.J. Jr., Crain, D.A., Rooney, A.A. and Pickford, D.B. (1998). Organization versus activation: The role of endocrinedisrupting contaminants (EDCs) during embryonic development in wildlife. Environ. Health Perspect., 103 (Suppl. 7): 157-164.

Gutiérrez-Yurrita, P.J. and Montes, C. (1998). Environmental factors controlling crayfish Procambarus clarkii activity in the Doñana National Park freshwater marsh (SW-Spain). Comp. Biochem. Physiol., Part A, 120: 713-721.

Laufer, H., Biggers, J.W. and Ahl, J.S.B. (1998). Stimulation of ovarian maturation in the crayfish Procambarus clarkii by methyl farnesoate. Gen. Comp. Endocrinol., 111: 113-118.

Naqvi, S.M. and Howell, R.D. (1993). Toxicity of cadmium and lead to juvenile red swamp crayfish, Procambarus clarkii, and effects on fecundity of adults. Bull. Environ. Contam. Toxicol., 51: 303-308.

Paulus, J.E. and Laufer, H. (1987). Vitellogenocytes in hepatopancreas of Carcinus maenas and Libinia emarginata (Decapoda: Brachyura). Int. J. Invertebr. Reprod. Dev., 11: 29-44.

Reddy, P.S., Tuberty, S.R. and Fingerman, M. (1997). Effects of cadmium and mercury on ovarian maturation in the red swamp crayfish, Procambarus clarkii. Ecotoxicol. Environ. Safety, 37: 62-65. profundo de los resultados debido a la pequeña cantidad de replicados. Sin embargo, los resultados obtenidos pueden tomarse en cuenta como una primera aproximación.

Durante los primeros días del accidente minero de Aznalcóllar, se ha demostrado que las concentraciones de metales pesados que contenía el vertido produjerom efectos biológicos adversos (Riba et al.,2003). Los efectos que se produjeron en la eficiencia de reproducción de las especies autóctonas no pudieron ser determinados en ese mismo momento, pero las concentraciones de metales pesados determinadas pudieron afectar a los organismos durante los primeros meses posteriores al vertido. En el presente estudio se han utilizado los procesos regulados a través del sistema hormonal como indicadores de la salud del medio ambiente, y se han probado en el laboratorio con concentraciones medioambientales reales. Sin embargo, deberían desarrollarse más estudios sobre el uso del GSI y el HSI como indicadores toxicidad en el medio ambiente porque, aunque se han mostrado relaciones entre GSI y HSI y la concentración disuelta de Zn, estos índices no muestran una tendencia clara en los individuos expuestos a Cd.

\section{Agradecimientos}

La realización de este trabajo ha sido subvencionada por una beca del Convenio PICOVER (Consejería de Medio Ambiente, Junta de Andalucía, España) y realizado en US Environmental Protection Agency, Pensacola, Fl. Los autores agradecen el apoyo y la ayuda de los miembros de la EPA por esta oportunidad y especialmente a Kathy, Tere y Andy por su apoyo incondicional durante el desarrollo de este estudio y por su amistad.

Traducido al español por los autores.

Riba, I., DelValls, T.A, Forja, J.M. and Gómez-Parra, A. (2002). Influence of the Aznalcóllar mining spill on the vertical distribution of heavy metals in sediments from the Guadalquivir estuary (SW, Spain). Mar. Pollut. Bull., 44(1): 39-47.

Riba, I., González de Canales, M., Forja, J.M. and DelValls. T.A. (2003). Sediment quality in the Guadalquivir estuary: Sublethal effects associated with the Aznalcóllar mining spill. Mar. Pollut. Bull. (in press).

Zou, E. (1997). Effects of sublethal exposure to zinc chloride on the reproduction of the water flea, Moina irrasa (Cladocera). Bull. Environ. Contam. Toxicol., 58: 437-141. 